\title{
MEKANISME PENERBITAN CEK DAN BILYET GIRO SEBAGAI ALAT PEMBAYARAN GIRAL PADA PT. BANK TABUNGAN NEGARA (Tbk) CABANG PADANG
}

\author{
Yegi Saputri, Jhon Fernos \\ Akademi Keuangan Perbankan "Pembangunan" Padang \\ Jhonfernos@akbpstie.ac.id
}

\begin{abstract}
Cheque are unconditionally warrant from the customer to the bank that maintains the customer's checking account, to pay some money to the parties mentioned therein or to the holder of the cheque. While the Giro is a warrant from the customer to the bank that maintains the customer's checking account to transfer a sum of money from the account in question to the recipients named in the same bank or another bank. Demand deposits (bank deposits) are funds or money held in checking accounts in commercial banks that can be used to perform a payment transaction through an intermediary cheque, giro, or orders to pay within a certain time. The purpose of the issuance of securities (cheque and demand deposits) is as fulfilling accomplishment in the form of payment of a sum of money in the form of demand deposits. Publishing mechanism checks and demand deposits at the State Savings Bank bnak together with other banks, because it is set by the central bank or Bank Indonesia Based on the analysis of the author, publishing mechanism and giro cheque above, the Issuer and the holders of the possibilities could be opened in the same bank or a different bank. Therefore, if a person does not have an account at a Bank Giro, the holder may act as recipients of cheque, but for Giro holder must have a checking account advance. Demand Deposit Account in payment by transferring funds is not an absolute requirement. Payment orders will be carried out by snagging when the issuer has a Giro account balances effective enough
\end{abstract}

Keywords : Publishing mechanism and giro cheque, demand deposits payment.

\section{PENDAHULUAN}

Perkembangan sistem pembayaran dari masa ke masa semakin berkembang pesat, manusia pada awalnya menggunakan sistem barter terus mengalami peningkatan perkembangan dengan menggunakan uang sebagai alat pembayaran, sehingga proses tukar menukar barang menjadi semakin efektif. Uang merupakan alat penukar dan pembayaran transaksi komersial dan finansial, sehingga uang menjadi pendorong kemajuan perekonomian dan perdagangan nasional dan internasional. Uang dibedakan menjadi uang kartal dan uang giral. Uang kartal adalah alat penukar yang terdiri dari uang pecahan kertas dan logam yang nilai nominalnya telah ditentukan oleh pemerintah, sedangkan uang giral adalah uang kertas dan nilai nominalnya ditentukan oleh penariknya masing-masing.

Sejarah telah mencatat bahwa tumbuhnya bank-bank pemerintah Indonesia ini tidak terlepas dari masa perjuangan negara Indonesia dalam melepaskan diri dari penjajahan. Dua masa penjajahan yang masih sangat jelas kita ingat adalah masa 
penjajahan Belanda dan Jepang. Bank BTN sebagai salah satu bagian yang tak terpisah dari bank milik pemerintah, tidak lepas dari masa perjuangan itu, dimana Bank BTN yang telah dikenal sejak tahun 1897 yang berkedudukan di Batavia (Jakarta) telah melakukan penghimpunan dana dalam bentuk simpanan untuk mendidik masyarakat agar gemar menabung. Bank Tabungan Negara (BTN) sepanjang perjalananya dalam mengukir sejarah dengan segala prestasi yang dimilikinya telah membuktikan peranya dalam menghubungkan kegemaran masyarakat Indonesia untuk menabung. Dengan semua usahanya maka BTN telah mengambil peran dalam usaha pembagunan disegala bidang diseluruh Indonesia. Dunia perbankan Indonesia yang berasaskan Demokrasi Ekonomi, yang mempunyai fungsi utama sebagai penghimpun dan penyalur dana masyarakat sesuai dengan ketentuan Undang-Undang.

Bank mempunyai kegiatan operasional, diantaranya jasa perbankan dalam aktivitas pembayaran menggunakan alat-alat pembayaran yang berupa uang maupun surat-surat berharga. Sistem pembayaran non tunai dalam perkembangannya berimplikasi luas terhadap berbagai aspek, antara lain : lembaga yang terlibat, aspek hukum pihak-pihak yang terkait, mekanisme pembayaran dan resiko. Dari berbagai aspek tersebut memberikan dampak terhadap sistem keuangan dan perekonomian sehingga memunculkan kebutuhan akan adanya suatu sistem pembayaran yang cepat, aman, dan mudah.

Lembaga perbankan Indonesia untuk memenuhi kebutuhan para nasabah, selain menghimpun dana dari masyarakat dan menyalurkan kembali kepada masyarakat, juga memberikan fasilitas buku formulir Cek, buku formulir Bilyet Giro, maupun bukubuku formulir surat berharga lainnya kepada para pemegang rekeningnya. Cek dan Bilyet Giro merupakan bagian dari jasa perbankan di Indonesia yang dilakukan oleh bank umum konvensional. Bank umum konvensional sangat berkaitan dengan kegiatan perekonomian masyarakat. Penggunaan Cek dan Bilyet Giro sebagai alat pembayaran mulai dirasakan oleh kalangan usaha, sehingga pengenalan dan penggunaan Cek dan Bilyet Giro merupakan tanda dimana masyarakat mengetahui peranan penting Cek dan Bilyet Giro sebagai alat pembayaran giral. Cek adalah surat yang memuat kata cek, yang diterbitkan pada tanggal dan tempat tertentu, dengan mana penerbit memerintahkan tanpa syarat kepada bankir untuk membayar sejumlah uang tertentu kepada pemegang atau pembawa, di tempat tertentu. Bilyet Giro adalah surat perintah dari nasabah kepada bank penyimpan dana untuk memindahbukukan sejumlah dana dari rekening yang bersangkutan kepada rekening pemegang yang telah disebutkan namanya. Terkait dengan penggunaan Cek dan Bilyet Giro sebagai alat pembayaran giral dalam transaksi perdagangan, PT.Bank Tabungan Negara (Persero) Tbk. Cabang Padang, sebagai salah satu perbankan konvensional yang menyediakan jasa perbankan, telah memberikan jasa melalui penerbitan dan pemindahbukuan penggunaan Cek dan Bilyet Giro kepada nasabah pemegang rekening giro di PT.Bank Tabungan Negara (Persero) Tbk. Cabang Padang.

Berdasarkan pada latar belakang di atas, maka pokok permasalahan yang akan dibahas dalam Tugas Akhir ini adalah sebagai berikut : "Bagaimana Mekanisme Penerbitan Cek dan Bilyet Giro Sebagai Alat Pembayaran Giral pada PT. Bank Tabungan Negara ( Persero ) tbk. Cabang Padang?” 


\section{LANDASAN TEORI \\ Pengertian Bank}

Pengertian bank menurut Undang-Undang Nomor 10 Tahun 1998 tentang Perubahan Atas Undang-Undang Nomor 7 Tahun 1992 tentang Perbankan dalam ketentuan Pasal 1 huruf $\mathrm{b}$ yang dimaksud dengan bank adalah badan usaha yang menghimpun dana dari masyarakat dalam bentuk simpanan dan menyalurkannya kepada masyarakat dalam bentuk kredit dan atau bentuk-bentuk lainnya daalm rangka meningkatkan taraf hidup rakyat banyak.

Pengertian diatas menjelaskan bahwa bank adalah suatu kegiatan yang menghimpun dana (funding) dan menyalurkan dana (leading) merupakan kegiatan utama perbankan. Aktivitas perbankan yang pertama adalah menghimpun dana dari masyarakat (kegiatan funding). Pengertian kegiatan funding adalah mengumpulkan atau mencari dana dengan cara membeli dari masyarakat luas.

\section{Fungsi Bank}

Secara umum fungsi bank adalah menghimpun dana dari masyarakat dan menyalurkannya kembali kepada masyarakat untuk berbagai tujuan atau fungsi Financial Intermediari. Fungsi bank ini dikemukakan oleh Susilo, triandoro dan Santoso (2006:9).

Fungsi utama bank ada 3 yaitu :

1. Bank berfungsi sebagaialat untuk menghimpun dan menyalurkan dana kepada masyarakat.

2. Funsi bank sebagai memobilisasi dana untuk pembangunan ekonomi suatu negara, dengan menghimpun dana dari masyarakat untuk berinvestasi terhadap pembangunan negara.

3. Bank berfungsi sebagai lembaga yang memberikan pelayanan kepada masyarakat, yang berupa jasa pelayanan perbankan kepada masyarakat agar mesyarakat merasa nyaman dan aman.

\section{Pengertian Surat Berharga}

Menurut Purwosutjipto (1998) mengatakan, surat berharga adalah surat bukti tuntutan utang yang sukar diperjualbelikan. Dan menurut Munir Fuady (1998) merumuskan, surat berharga adalah sebuah dokumen yang diterbitkan oleh penerbitnya sebagai pemenuhan suatu prestasi berupa pembayaran sejumlah uang sehingga berfungsi sebagai alat pembayaran yang di dalamnya berisikan suatu perintah untuk membayar kepada pihak-pihak yang memegang surat tersebut.

Tujuan adanya penerbitan surat berharga adalah sebagai pemenuhan prestasi berupa pembayaran sejumlah uang. Secara yuridis Surat Berharga mempunyai 3 (tiga) fungsi utama yaitu :

1. Sebagai alat pembayaran (alat tukar).

2. Sebagai alat untuk memindahkan hak tagih (diperjualbelikan dengan mudah atau sederhana).

3. Sebagai surat bukti hak tagih (surat legitimasi).

Jenis-jenis Surat Berharga Secara garis besar apabila ditinjau dari segi pengaturan, maka Surat Berharga dapat dibedakan atas dua golongan, yaitu :

1. Surat wesel.

Menurut H. M. N. Purwosutjipto (2000) yang dimaksud dengan wesel adalah surat berharga yang memuat kata wesel di dalamnya, ditanggali dan ditandatangani di suatu tempat, dalam mana penerbit (tekker) memberi perintah tak bersyarat kepada tersangkut (betrokkene) untuk membayara sejumlah uang pada hari bayar 
(vervaldag) kepada orang yang di tunjuk oleh penerbit yang disebuut penerima (nemer) atau penggantinya di suatu tempat tertentu.

2. Surat sanggup.

Undang-undang tidak memberikan rumusan atau definisi surat sanggup, dalam ketentuan Pasal 174 KUHD dimuat syarat-syarat formal sepucuk surat sanggup. Syarat-syarat formal tersebut dapat dirumuskan atau definisi surat sanggup adalah sebagai surat yang memuat kata surat sangup atau promesse aan order, yang ditandatangani pada tangal dan tempat tertentu, dengan mana penandatangan menyanggupip tanpa syarat untuk membayar sejumlah uang tertentu kepada pemegang atau penggantinya pada tanggal dan tempat tertentu.

3. Surat cek

Pada mulanya istilah "Cek" berasal dari kata "cheque" (bahasa Perancis), istilah tersebut juga digunakan Belanda dan Inggris. Definisi tentang cek sebenarnya tidak dirumuskan dalam peraturan perundang-undangan ketentuan mengenai syaratsyarat formal cek terdapat di dalam Pasal 178 KUHD Pengertiannya adalah surat yang memuat kata cek, diterbitkan pada tanggal dan tempat tertentu dimana penerbit memerintahkan tanpa syarat kepada bankir untuk membayar sejumlah uang tertentu kepada pemegang atau pembawa di tempat tertentu.

4. Kwitansi dan Promes atas tunjuk.

Kata kwitansi berasal dari kata bahasa Belanda yaitu kwitantie, artinya tanda pemabayaran, bahasa Inggrisnya yaitu receipt. Pengaturan kwItansi atas tunjuk dalam ketentuan Pasal 229f, 229g, dan 229h KUHD. Pengertian Kwitansi adalah surat yang diterbitkan oleh penanda tangan pada tanggal dan tempat tertentu yang berisi perintah membayar sejumlah uang tertentu kepada pemegang pada saat diperlihatkan.

Kata promes berasal dari kata bahasa Perancis promesse artinya sanggup atau janjji, yaitu sanggup membayar atau janji membayar. Pengaturan promes atas tunjuk dalam ketentuan Pasal 229i KUHD.

\section{Cek (Cheque)}

\section{Pengertian Cek}

Berdasarkan Undang-Undang No. 10 tahun 1998 cek adalah surat perintah tanpa syarat dari nasabah kepada bank yang memelihara rekening nasabah tersebut untuk membayar sejumlah uang kepada pihak yang disebutkan didalamnya atau kepada seseorang yang membawa cek tersebut. Menurut Kamus Besar Bahasa Indonesia, cek adalah perintah tertulis pemegang rekening kepada bank yang ditunjuknya supaya membayar sejumlah uang pemegangnya.

2. Syarat Hukum Cek

Syarat hukum dan penggunaan cek sebagai alat pembayaran giral seperti yang diatur dalam KUH Dagang pasal 178 dengan syarat yaitu :

a. Pada surat cek tertulis perkataan "CEK"

b. Surat cek harus berisi perintah tak bersyarat untuk memebayar sejumlah uang tertentu

c. Nama bank yang harus membayar (tertarik)

d. Penyambutan tanggal dan tempat cek dekeluarkan

e. Tanda tangan penarik

3. Jenis-jenis Cek 
Penarikan dana dengan menggunakan sarana cek disamping persyaratan diatas juga sangat tergantung dari jenis-jenis cek yang dikeluarkan oleh si pemberi cek. Adapun jenis-jenis cek yang dimaksud adalah :

a. Cek atas Nama

Merupakan cek yuang diterbitkan atas nama orang atau badan tertentu yang tertulis jenis di dadam cek tersebut. Misalnya bayarlah kepada Tn. Roy Akase sejumlah Rp 3000.000;

b. Cek atas Unjuk

Yaitu cek yang tidak tertulis nama seseorang atau badan tertentu di dalam cek tersebut.

c. Cek Silang

Jika suatu cek yang dipojok kiri atas diberi dua tanda silanhg sehingga cek tersebut berfungsi sebagai pemindahbukuan bukan tunai.

d. Cek Mundur

Yang merupakan cek yang diberi tanggal mundur dari tanggal sekarang, misalnya hari tanggal 01 mei 2001, Tn Roy Akase bermaksut mencairkan ceknya dimana dalam cek tersebut tertulis tanggal 5 mei 2001. Jenis cek inilah yang desbut dengan cek mundur, hal ini biasa terjadi karena ada kesepakatan antara sipemberi cek dengan sipenerima cek

e. Cek Kosong

Yaitu cek yang dananya tidak tersedia sebagai contoh misalnya nasabah menarik cek senilai 66 juta rupiah tertulis didalam cek tersebut, akan tetapi dana yang tersedia di rekening giro tersebut hanya ada 20 juta rupiah. Jelas cek tersebut kurang jumlahnya dibandingkan dengan jumlah dana yang ada.

4. Pembayaran dan tenggang waktu penawaran.

Menurut keentuan Pasal 206 KUHD, suatu cek yang diterbitkan atau harus dibayar di Indonesia, harus diperlihatkan untuk pembayarannya daalm tenggang waktu 70 hari. Tenggang waktu ini berjalan mulai hari tanggal penerbitannya. Apabila dihubungkan dengan penerbitan surat cek bertanggal mundur maksudnya ialah untuk memperpanjang waktu beredarnya sehingga melebihi jangka waktu 70 hari itu, mungkin disebabkan saat cek diserahkan dananya belum cukup tersedia, sehingga untuk menyakinkan penerimanya maka cek dibuat bertanggal mundur.

\section{Penjelasan Bilyet Giro}

\section{Pengertian Bilyet Giro}

Menurut H. M. N. Purwosutjipto (2000), bilyet giro adalah surat perintah tak bersyarat dari nasabah yang telah dibakukan bentuknya, kepada bank penyimpan dana untuk memindahkan sejumlah dana dari rekening giro yang bersangkutan kepada pihak penerima yang sebutkan namanya, kepada bank tersebut.

Menurut ketentuan Undang-Undang Nomor 10 Tahun 1998 tentang Perbankan, bilyet giro adalah salah satu cara untuk melakukan pemindahbukuan terhadap simpanan dalam bentuk giro yang dapat dilakukan oleh setiap nasabah yang bersangkutan.

Berbagai pengertian bilyet giro diatas mengandung unsur-unsur sebagai berikut:

a. Surat perintah.

b. Dari nasabah penyimpan kepada bank.

c. Pemindahbukuan sejumlah uang dari rekening yang bersangkutan.

d. Sejumlah uang tersebut ditujukan kepada penerima yang disebutkan namanya. 
2. Syarat Hukum Bilyet Giro

Syarat-syarat penerbitan Bilyet Giro harus memenuhi sesuai dengan ketentuan yang diatur dalam Pasal 2 ayat (1) Surat Keputusan Direksi Bank Indonesia Nomor 28/32/KEP/DIR tahun 1995 yaitu :

a. Nama dan nomor Bilyet Giro yang bersangkutan.

b. Nama tertarik.

c. Perintah yang jelas dan tanpa syarat untuk memindahbukukan dana atas beban rekening penarik.

d. Nama dan nomor rekening pemegang.

e. Nama bank pemerima.

f. Jumlah dana yang dipindahbukukan baik dalam angka maupun huruf selengkap-lengkapnya.

g. Tempat dan tanggal penarikan.

h. Tanda tangan, nama jelas, dan atau dilengkapi dengan cap / stempel sesuai dengan persyaratan pembukuan rekening.

Berdasarkan uraian tersebut Bilyet Giro merupakan alat pembayaran sehingga termasuk juga sebagai surat berharga. Sebagai surat perintah pemindahbukuan, Bilyet Giro tidak dapat dilakukan pembayarannya dengan uang tunai.

3. Pembayaran dan tenggang waktu pembayaran

Masa penawaran Bilyet Giro diatur dalam Pasal 6 ayat 1 Keputusan Direksi Bank Indonesia Nomor 28/32/KEP/DIR tahun 1995 yaitu tenggang waktu yang diberikan adalah 70 hai terhitung sejak tanggal penarikan, apabila sebelum tanggal efektif harus ditolak oleh bank yang bersangkutan. Tenggang waktu penawaran selama 70 hari mempunyai 2 (dua) fungsi yaitu:

a. Untuk membatasi penetapan tanggal efektif.

b. Untuk batas waktu tidak diperkenankannya penarik membatalkan Bilyet Giro yang bersangkutan.

Bilyet giro ditawarkan setelah berkahirnya tenggang waktu penawaran dapat dipindahbukukan, menurut ketentuan Pasal 6 ayar 3 Keputusan Direksi Bank Indonesia Nomor 28/32/KEP/DIR tahun 1995 bahawa bilyet giro yang diterima oleh bank setelah tanggal berakhirnya tenggang waktu penawaran dapat dilaksanakan perintahnya sepanjang dananya tersedia dan tidak dibatalkan oleh penarik.

Syarat mengenai tanggal efektif berkaitan dengan kadaluwarsanya (batas waktunya) serta batas waktu penyediaan dana bagi penarik, namun demikian hal tersebut tidak jelas diatur dan merupakan kelemahan dari peraturan mengenai bilyet giro.

Suatu transaksi perdagangan yang pembayarannya menggunakan bilyet giro, maka kemudahan-kemudahan yang akan diperoleh nasabah sebagai berikut :

a. Bebas bea materai.

b. Lebih aman penggunaannya.

c. Kewajiban penyedia dana.

d. Pelaksanaan amanat sampai pada tujuannya.

e. Dapat dibatalkan.

4. Perbedaan Bilyet Giro dengan Cek

a. Sifat 
Cek merupakan surat berharga yang dapat diuangkan secara tunai pada bank yang ditunjuk. Sedangkan bilyet giro sendiri merupakan surat berharga yang tidak dapat diuangkan secara tunai.

b. Pembayaran

Jika dilihat dari cara pembayarannya, pembayaran yang menggunakan cek bisa dilakukan atas unjuk dari bank tertentu. Sedangkan pembayaran menggunakan bilyet giro haruslah dilakukan oleh pihak ketiga yang namanya terdapat atau tertera pada bilyet giro tersebut.

c. Bea Materai

Penarikan menggunakan cek maka dikenakan bea materai. Tapi penarikan menggunakan bilyet giro tidak dikenakan bea.

d. Tanggal Berlaku

Untuk surat berharga cek, terdapat istilah yaitu cek mundur atau tanggal berlaku ini dapat diperpanjang cek mundur ini dapat terjadi jika kedua belah pihak setuju atau sepakat. Sedangkan untuk surat berharga bilyet giro, terdapat tanggal berlaku dan juga tanggal efektif surat perintah yang bersangkutan.

e. Tanggal penyerahan

Jika menggunakan cek, pihak bank tidak dapat menguangkan surat berharga tersebut jika belum ada tanggal penerbit pada surat perintah tersebut. Sedangkan bilyet giro dapat secara langsung diserahkan oleh pihak bank walaupun belum mencapai tanggal efektif. Dengan syarat jika tanggal efektif tersebut lebih awal dibandingkan tanggal penerbit dari bilyet giro tersebut.

\section{Transaksi Cek dan Bilyet Giro antar Bank}

Transaksi cek dan bilyet giro antar bank disebut dengan kliring, Pengertian dari Kliring adalah tata cara penghitungan ataupun penyelesaian utang-piutang dalam bentuk surat-surat berharga terhadap Bank lain agar penyelesaiannya dapat terselenggara dengan mudah, cepat, dan aman serta memperlancar lalu lintas pembayaran dengan menggunakan uang giral. Lalu lintas pembayaran merupakan suatu proses kegiatan pembayaran dengan warkat Kliring yang dilakukan dengan cara memperhitungkan diantara Bank-Bank, baik atas beban maupun untuk keuntungan nasabah yang bersangkutan. PBI No. 7/18/PBI/2005 kliring adalah Pertukaran warkat atau data keuangan elektronik antar peserta kliring atas nama peserta maupun nasabah.

\section{Tinjauan Tentang Uang Giral}

Uang giral tercipta akibat semakin mendesaknya kebutuhan masyarakat akan adanya sebuah alat tukar yang lebih mudah, praktis dan aman. Di Indonesia, bank yang berhak menciptakan uang giral adalah bank umum selain Bank Indonesia. Menurut UU No. 7 tentang Perbankan tahun 1992, definisi uang giral adalah tagihan yang ada di bank umum, yang dapat digunakan sewaktu-waktu sebagai alat pembayaran. Uang giral (simpanan di bank) ialah dana atau uang yang disimpan pada rekening koran di bankbank umum yang bisa dipakai untuk melakukan sebuah transaksi pembayaran melalui perantara cek, bilyet giro, atau perintah membayar dalam waktu tertentu.

\section{METODE PENELITIAN}

Dalam pengumpulan data dan bahan-nahan untuk melakukan penelitian ini, digunakan metode-metode pengumpulan data sebagai berikut :

1. Metode Pengumpulan Data

a. Studi Lapangan (Field Research) 
Peninjauan langsung ke objek penelitian yang dipilih untuk meneliti hasil data primer dan membantu penulis melengkapi data yang diperlukan. Adapun cara riset ini adalah dengan mewawancarai pihak-pihak yang berkepentigan dalam hal ini adalah perusahaan atau instansi yang terkait.

b. Studi Kepustakaan (Library Research)

Penilaian yang dilakukan ke perpustakaan beberapa buku-buku ilmiah dan tulisan-tulisan yang berhubungan dengan pembahasan yang dilakukan.

2. Metode Analisa Data

Dalam menganalisa data, penulis menggunakan analisis data kuantitatif sebagai metode penelitianyang menjelaskan secara deskriptif mengenai bagaimana mekanisme penerbitan cek dan bilyet giro sebagai alat pembayaran giral pada PT. Bank Tabungan Negara ( Persero ) tbk. Cabang Padang.

\section{HASIL DAN PEMBAHASAN \\ Mekanisme Penerbitan Cek dan Bilyet Giro}

Mekanisme penerbitan cek dan bilyet giro pada Bank Tabungan Negara sama dengan bnak-bank lain, karena sudah diatur oleh bank pusat atau Bank indonesia. Sedangkan mekanisme penerbitan cek dan bilyet giro pada bank BTN yaitu, Seorang nasabah pergi ke Bank BTN untuk menerbitkan Cek dan Bilyet Giro dan mengambil nomor antrian sesuai dengan tujuan nasabah tersebut, ketika nomor nasabah tersebut dipanggil nasabah langsung menghampiri customer service (CS), menceritakan maksud dan tujuannya, setelah nasabah selesai menceritakan maksud dan tujuannya untuk menerbitkan cek dan bilyet giro, lalu CS yang bertanya kepada nasabah tersebut apakah memiliki rekening giro, apabila nasabah tersebut tidak memiliki rekening giro maka nasabah tersebut harus membuka rekening girodengan setoran awal minimal $\mathrm{Rp}$ 500,000; atas nama perorangan dan giro atas nama badan Rp 1000,000;, dan apabila nasabah sudah memiliki rekening giro maka CS akan meminta bukti penerbitan buku Cek/ BG dari nasabah tersebut. Setelah CS menerima bukti penerbitan buku Cek/ BG, CS menyerahkan bukti penerbitan buku cek/ BG kepada unit Transaksi Prosesing (TP) dengan menyediakan register sudah terima. Lalu unit Transaksi Prosesing TP memproses dokumen yang diberikan customer service atas permintaan nasabah dan unit TP juga memeriksa apakah data-data tersebur memang benar adanya baru bisa diproses melalui Bank Indonesia (BI). Setelah cek/ BG tersebut sudah selesai diterbitkan atau dibuat, kemudian unit Transaksi Prosesing (TP) diberikan lagi kepada CS, dan yang terakhir baru CS menyerahkan Cek/ BG tersebut kepada nasabah.

Terjadinya penerbitan cek dan bilyet giro karena adanya permintaan dari nasabah untuk menerbitkan cek dan bilyet giro pada bank tersebut. Cek dan bilyet giro bisa diterbitkan nasabah dengan membuka rekening giro untuk bisa melakukan transaksi dalam lalu lintas pembayaran giral, yang bertujuan untuk meningkatkan taraf hidup rakyat banyak.

Permasalahan yang akan terjadi apabila nasabah menerbitkan cek dan bilyet giro kosong, dan jika nasabah melakukan kesalahan tersebut hingga tiga kali maka rekening gironya akan di black list oleh Bank Indonesia.

\section{Data Nasabah Pengguna Cek dan Bilyet Giro}

Nasabah Bank BTN yang menerbitkan cek dan bilyet giro selama tahun 2016 adalah 30 orang nasabah, pada bulan januari dan februari tidak mengalami peningkatan nasabah yang menerbitkan cek dan bilyet giro masing-masing tiga orang nasabah, pada bulan maret mengalami peningkatan daritiga menjadi tujuh nasabah, pada bulan april 
mengalami penurunan dari tujuh menjadi empat orang nasabah, pada bulan may dan juni mengalami peningkatan dari empat menjadi enam orang nasabah, pada bulan juli mengalami penurunan yang tajam dari enam orang nasabah menjadi satu orang nasabah, pada bulan agustus mengalami peningkatan tiga orang nasabah, pada bulan september mengalami peningkatan yang sangat tajam yaitu sebelas orang nasabah, pada bulan oktober mengalami penurunan menjadi 4 orang nasabah, pada bulan november mengalami peningkatan menjadi enam orang nasabah, dan pada bulan desember mengalami penurunan dari enam orang nasabah menjadi empat orang nasabah. Sehingga penggunaan cek dan bilyet giro cenderung mengalami peningkatan dari bulan ke bulan, apalagi dari tahun ke tahun, terutama dari kalangan pedagang yang menggunakannya sebagai alat pembayaran dalam transaksi perdagangan yang jumlahnya sangat besar.

Faktor-faktor pendorong nasabah dalam menggunakan Cek dan Bilyet Giro

Faktor-faktor pendorong nasabah BTN Cabang Padang menggunakan Cek dan Bilyet Giro, antara lain disebabkan karena lebih aman, kewajiban penyedia dana, sampai pada tujuannya, anjuran dari Bank Indonesia, dan lain-lain.

\section{Pemindahbukuan}

Dalam Pemindahbukuan Cek dan Bilyet Giro dapat dilakukan oleh bank yang sama yaitu Bank Tabungan Negara ke Bank Tabungan Negara lainnya maupun dari Bank Tabungan Negara ke Bank yang lain melalui kliring atau transaksi antar bank yang diadakan oleh Bank Indonesia.

\section{Pembahasan}

Pada penjelasan mekanisme penerbitan cek dan bilyet giro di atas, Penerbit dan pemegang kemungkinan bisa dibuka pada Bank yang sama atau pada Bank yang berbeda. Oleh karena itu, apabila seseorang tidak mempunyai rekening Giro pada suatu Bank, maka pemegang mungkin bertindak sebagai penerima Cek, akan tetapi untuk Bilyet Giro pemegang harus mempunyai rekening giro terlebih dahulu. Rekening Giro dalam pembayaran melalui pemindahbukuan dana bukan merupakan syarat mutlak. Perintah pembayaran akan dilaksanakan oleh tersangkut apabila rekening Giro penerbit mempunyai saldo efektif yang cukup. Manfaat dan efektif pengguna Cek dan Bilyet Giro di kalangan masyarakat khususnya masyarakat pedagang dibagi dalam 2 segi yaitu

1. Segi Ekonomi :

a. Penundaan pembayaran yang berkaitan dengan beban bunga.

b. Sebagai barang atau jaminan akan tersedianya dan pada waktu yang telah ditentukan.

c. Sebagai alat kelancaran lalu lintas perdagangan.

2. Segi Praktis :

a. Mudah dan praktis dalam membawa dan menyimpannya.

b. Menghemat waktu dan tidak memerlukan perhitungan lama.

c. Dapat dipindahtangankan dengan orang lain dengan cara peralihan.

d. Lebih aman dari resiko kehilangan.

e. Dapat langsung diuangkan sesuai dengan klausul perjanjian

Mengenai faktor-faktor pendorong penggunaan Cek dan Bilyet Giro di Bank

BTN Cabang Padang:

1. Lebih aman.

Apabila terjadi kehilangan, pencurian atau pun lepas dari kekuasaan pemiliknya, Cek dan Bilyet Giro yang telah diisi lengkap nama dan Bank penerima dana, maka 
Cek dan Bilyet Giro itu tidak dapat digunakan oleh orang lain. Cek dan Bilyet Giro juga tidak dapat dibayar dengan uang tunai. Dengan demikian penggunaan Cek dan Bilyet Giro adalah lebih aman.

2. Kewajiban penyediaan dana.

Cek dan Bilyet Giro penyediaan dana oleh penerbit baru timbul pada saat tanggal efektif tiba (jatuh tempo). Sebelumnya masih ada kesempatan bagi penerbit untuk berusaha mencari dana. Pengajuan Cek dan Bilyet Giro sebelum tanggal efektif tiba (jatuh tempo) maka akan ditolak oleh Bank tanpa memperhatikan apakah dananya cukup atau tidak.

3. Sampai pada tujuannya.

Cek dan Bilyet Giro yang telah diisi lengkap oleh penerbit, maka tidak dapat beredar lagi dan penerbit dapat mengetahui segera bahwa dananya sudah dipindahbukukan ke dalam rekening orang yang ditujunya atau penerima.

4. Dapat dibatalkan.

Selama amanat dalam Bilyet Giro belum dilaksanakan oleh Bank yang bersangkutan, maka Bilyet Giro tersebut dapat dibatalkan oleh penerbitnya. Faktor ini merupakan penolong yang sangat tepat bagi penerbit yang kebetulan berhubungan dengan pihak yang tidak jujur, beritikat buruk atau wanprestasi.

5. Anjuran Bank Indonesia

Karena pengaruh peredaran uang kartal, Bank Indonesia menganjurkan kepada para nasabah Bank atau pemilik rekening Giro agar supaya selain menggunakan surat Cek, juga menggunakan Bilyet Giro yaitu alat pembayaran dengan cara pemindahbukuan. Hal ini ada pengaruhnya terhadap peredaran uang kartal.

6. Kepastian Hukum.

Bilyet Giro maupun Cek tidak dapat dibatalkan selama tenggang waktu penawaran, sehingga pemegang merasa terjamin kepastian haknya memperoleh pembayaran dengan pemindahbukuan melalui Bilyet Giro dan Cek yang ditawarkan oleh bank tertarik.

Tentang pemindahbukukan rekening giro untuk penggunaan Cek dan Bilyet Giro. Rekening Giro tersebut mungkin tersimpan pada Bank yang sama atau mungkin pada Bank yang berbeda. Apabila tersimpan pada Bank yang sama, maka pemindahbukuan dana tersebut mudah untuk dilaksanakan yaitu dengan cara mengurangi rekening Giro penerbit, kemudian ditambahkan ke rekening Giro pemegang. Tetapi apabila pemindahbukuan tersebut harus dilakukan dengan Bank yang berbeda, maka pelaksanaan administrasi pemindahbukuan tersebut dilakukan dengan cara Kliring. Lembaga Kliring yang diadakan oleh Bank Indonesia atau bank lain yang ditunjuk untuk itu, mengadakan pertemuan kliring setiap hari, dimana setiap wakil dari bank-bank peserta kliring harus hadir tepat waktu. Untuk keterlambatan lebih dari sepuluh menit setelah pertemuan kliring dimulai tidak akan diperbolehkan mengajukan tagihan-tagihan kepada kepada bank peserta kliring lain, tetapi hanya boleh menerima tagihan-tagihan dari bank peserta kliring yang lain. Adapun perhitungan atas Bilyet Giro yang diterima oleh Bank BRI dari nasabah yang lain, akan dihitung bersama-sama dengan warkat-warkat kliring yang lain.

\section{SIMPULAN}

Berdasarkan penelitian dan pembahasan yang telah penulis lakukan mengenai mekanisme penerbitan cek dan bilyet giro sebagai alat pembayaran giral pada PT. Bank 
Tabungan Negara (Persero) Tbk. Cabang Padang, maka dikemukakan kesimpulan sebagai berikut:

1. Manfaat penggunaan cek dan bilyet giro adalah mempermudah nasabah dalam bertransaksi dan memberi keringanan kepada nasabah untuk tidak perlu membawa uang tunai dalam jumlah yang banyak.

2. Mekanisme penerbitan cek dan bilyet giro pada PT. Bank Tabungan Negara (Persero) Tbk. Cabang Padang adalah sebagai berikut :

a. Nasabah menemui Customer Service

b. Membuka rekening giro (Jika belum ada)

c. Menyerahkan bukti penerbitan buku cek dan bilyet giro ke customer service.

d. Bukti penerbitan buku cek dan bilyet giro diserahkan ke unit Tranaksi Prosesing (TP)

e. TP memproses data yang sudah diberikan Customer Service.

f. Setelah penerbitan cek dan bilyet giro selesai oleh TP, TP memberikan cek dan bilyet giro tersebut ke Customer Service.

g. Setelah selesai diterbitkan, cek dan bilyet giro diserahkan ke nasabah dan memeriksanya.

3. Faktor-faktor pendorong nasabah BTN Cabang Padang menggunakan Cek dan Bilyet Giro, antara lain disebabkan karena lebih aman, kewajiban penyedia dana, sampai pada tujuannya, anjuran dari Bank Indonesia, dan lain-lain.

4. Pemindahbukukan rekening giro untuk penggunaan Cek dan Bilyet Giro. Rekening Giro tersebut mungkin tersimpan pada Bank yang sama atau mungkin pada Bank yang berbeda. Apabila tersimpan pada Bank yang sama, maka pemindahbukuan dana tersebut mudah untuk dilaksanakan yaitu dengan cara mengurangi rekening Giro penerbit, kemudian ditambahkan ke rekening Giro pemegang. Tetapi apabila pemindahbukuan tersebut harus dilakukan dengan Bank yang berbeda, maka pelaksanaan administrasi pemindahbukuan tersebut dilakukan dengan cara Kliring melalui Lembaga Kliring setempat.

\section{DAFTAR PUSTAKA}

Abdulkadir, Muhammad, Hukum Dagang Surat-Surat Berharga, (PT. Citra Aditya Bhakti, Bandung). 1998, hal. 5.

Anwari, Achmad, (1980), Bilyet Giro, Balai Aksara, Jakarta.

http://1t4juwita.wordpress.com/2011/03/19/jasa-jasa-bank-fee-base-income/

http://www.btn.co.id/Produk/Produk-Jasa/Inkaso.aspx.

Kasmir, (1999), Bank dan Lembaga Keuangan lainnya, PT. Raja Grapindo Persada: Jakarta.

Kasmir, 2010, Dasar - Dasar Perbankan, Jakarta : PT. Raja Grafindo Persada.

Kasmir, (2011), Bank dan Lembaga Keuangan Lainnya, PT. Raja Grafindo Persada: Jakarta.

M. Bahsan, Cek dan Bilyet Giro Perbankan Indonesia, PT. Raja Grafindo Perkasa, Jakarta, 2006, hal.1. 
M. Bahsan, (2005), Cek dan Bilyet Giro Perbankan Indonesia, PT. Raja Grafindo Perkasa, Jakarta

Malayu SP Hasibuan, 2005, Dasar - Dasar Perbankan, Jakarta : Bumi Aksara.

Muhammad, Abdulkadir, 1998, Hukum Dagang Tentang Surat - Surat Berharga, Bandung : PT.Citra Aditya Bakti

Peraturan Bank Indonesia Nomor 8/ 29 /PBI/2006 tentang Daftar Hitam Nasional

Penarik Cek Dan /Atau Bilyet Giro Kosong

Purwosujipto, H.M.N, 2000, Pengertian Pokok Hukum Dagang Indonesia SuratSurat Berharga, Jilid 7 Cetakan ke 5, Jakarta : Jambatan.

Safitri, R. N., \& Marlius, D. (2017). Penerapan E-Banking Dalam Meningkatkan Jasa Dan Layanan Perbankan Di PT. Bank Rakyat Indonesia Cabang Padang. https://doi.org/10.31227/osf.io/gkv8t

Subagyo, dkk, (1997), Bank dan Lembaga Keuangan Lainnya, Yogyakarta: STIE YKPN.

Surat Edaran Bank Indonesia No. 28/32/UPG/1995 Tentang Pengaturan Bilyet Giro

Undang-Undang Pokok Perbankan Nomor 7 Tahun 1992.

Undang-Undang No. 10 Tahun 1998 Tentang Perbankan.

Undang- Undang Hukum Dagang (KUHD)

www.bi.go.id/web/id/Sistem+Pembayaran/ 